\title{
Geochemical evolution of groundwater in southern Bengal Basin: The example of Rajarhat and adjoining areas, West Bengal, India
}

\author{
Paulami Sahu ${ }^{1, *}$, P K Sikdar ${ }^{2}$ and Surajit Chakraborty ${ }^{2}$ \\ ${ }^{1}$ School of Environment and Sustainable Development, Central University of Gujarat, Gandhinagar 382 030, India. \\ ${ }^{2}$ Department of Environment Management, Indian Institute of Social Welfare and Business Management, \\ Kolkata 700 073, India. \\ *Corresponding author.e-mail: paulami_sahu@cug.ac.in
}

Detailed geochemical analysis of groundwater beneath $1223 \mathrm{~km}^{2}$ area in southern Bengal Basin along with statistical analysis on the chemical data was attempted, to develop a better understanding of the geochemical processes that control the groundwater evolution in the deltaic aquifer of the region. Groundwater is categorized into three types: 'excellent', 'good' and 'poor' and seven hydrochemical facies are assigned to three broad types: 'fresh', 'mixed' and 'brackish' waters. The 'fresh' water type dominated with sodium indicates active flushing of the aquifer, whereas chloride-rich 'brackish' groundwater represents freshening of modified connate water. The 'mixed' type groundwater has possibly evolved due to hydraulic mixing of 'fresh' and 'brackish' waters. Enrichment of major ions in groundwater is due to weathering of feldspathic and ferro-magnesian minerals by percolating water. The groundwater of Rajarhat New Town (RNT) and adjacent areas in the north and southeast is contaminated with arsenic. Current-pumping may induce more arsenic to flow into the aquifers of RNT and Kolkata cities. Future large-scale pumping of groundwater beneath RNT can modify the hydrological system, which may transport arsenic and low quality water from adjacent aquifers to presently unpolluted aquifer.

\section{Introduction}

Large cities face water quality and quantity problems due to increasing population, over withdrawal and improper disposal of solid and liquid wastes (Brindha et al. 2014). These problems are also very prominent in the urban areas of Bengal Basin, especially in the southern Bengal Basin (Sikdar et al. 2001). This basin has profuse groundwater resources (Mukherjee et al. 2009) but often with concentration of arsenic (As) higher than the World Health Organization's guideline value of $10 \mu \mathrm{g} / \mathrm{L}$ (Chakraborti et al. 2002; McArthur et al. 2004, 2012a, b; Mukherjee et al. 2008; Fendorf et al. 2010; Hoque et al. 2012; Sikdar et al. 2013; Ghosal et al. 2014). As is mainly released from recent sediments at $<50 \mathrm{~m}$ depth as sea level rose throughout the Holocene (Dowling et al. 2002). The pollution is caused primarily by, or as a side reaction of, the microbial reduction of sedimentary Fe(III)oxyhydroxides, when $\mathrm{As}(\mathrm{V})$ is reduced to $\mathrm{As}(\mathrm{III})$ when in solution and not when bound to $\mathrm{Fe}$ (Osborne et al. 2015).

Intense agricultural, industrial and urban expansion has led to high demand of groundwater which has resulted in rapid fall in the water level and variation in groundwater chemistry (Lakshmanan et al. 2003; Rajmohan and Elango 2006; Brindha and Elango 2012). In such areas, the assessment of groundwater resource is a key to economic

Keywords. Water quality index; hydrochemical facies; principal component analysis; groundwater evolution. 
development and increased prosperity. Many studies have focussed on evaluation of recharge, its sources, groundwater flow paths and their travel times by numerical modelling, geochemical modelling and environmental isotopes (Adar and Neuman 1988; Edmunds and Gaye 1994; Weyhenmeyer et al. 2002; Macumber 2003; Mukherjee and Fryar 2008; Michael and Voss 2009a, b; Sahu et al. 2013; Sikdar et al. 2013) and to lesser extent on variation of groundwater chemistry and evolution of groundwater types. Variation in groundwater chemistry and evolution of groundwater types is mainly a function of the interaction between groundwater and mineral grains of the aquifer and is controlled by various factors such as precipitation, evaporation, dissolution, weathering of silicate minerals, oxidation-reduction, sorption and exchange reactions, transformation of organic matter and mixing processes (Sikdar et al. 2001; Rajmohan and Elango 2006; Carrilo-Rivera et al. 2007; Saha et al. 2008; Sahu and Sikdar 2008; Sharif et al. 2008; Sikdar and Chakraborty 2008; Pazand 2013). Characterization of groundwater into geochemical types and knowledge of geochemical evolution of groundwater quality is essential to understand the hydrogeochemical systems of mega-cities around the world (Ballukraya and Ravi 1999; Azaza et al. 2011).

This study aims to demarcate, for the first time, the area in and around Rajarhat New Town into groundwater zones on the basis of quality and to understand processes controlling the geochemical evolution of different groundwater types. This may help to support new and more efficient groundwater management programmes to combat deterioration of groundwater quality in a stressed city aquifer of southern Bengal Basin.

\section{Study area}

The study area covers about $1223 \mathrm{~km}^{2}$ in southern Bengal Basin (figure 1). The area forms a part of the lower deltaic plain of the River Hugli, and slopes gradually towards south and southeast. The area is generally flat in nature with elevations varying between 3.5 and $12.1 \mathrm{~m}$ above the mean sea level because of the presence of palaeo-levees and palaeo-channels. Hot lengthy summer with occasional nor'westers, prolonged monsoon from June to October, mild winter and a brief spring, characterize the climate of the study area. The average annual rainfall, mostly from southwest monsoon, is about $1650 \mathrm{~mm}, 80 \%$ of which occurs during June to September. The annual maximum and minimum temperatures are $42^{\circ}$ and $10^{\circ} \mathrm{C}$, respectively.

Kolkata city along with its satellite cities of Salt Lake and upcoming Rajarhat New Town (RNT) is the major pumping centre of the study area. Kolkata's basic structure was laid down during the Imperial rule, when it became the major port city of the British Empire passing through various phases of trading, administrative and military roles. The city is located on the eastern levee and flood plain of the River Hugli and is bordered by a large area of brackish lakes towards its east. Because of this peculiar physical setup, the city was forced to grow as a lineal city paralleling $\mathrm{N}-\mathrm{S}$ course of the river. In the post-independence period (from 1947), the city has grown precipitously in the south. Economic opportunities had attracted people from all parts of India over the last few decades. The population growth accelerated as a result of heavy influx of displaced persons from erstwhile East Bengal (now Bangladesh). To accommodate the increasing population of Kolkata, Salt Lake city $\left(22.35^{\circ} \mathrm{N}, 88.25^{\circ} \mathrm{E}\right)$ with an area of $12.35 \mathrm{~km}^{2}$ was developed on the marshy tract on the eastern fringe of Kolkata between 1958 and 1965. Now, it is a very highly developed part of Kolkata. To accommodate the still growing population of Kolkata, another satellite township of RNT covering an area of $28 \mathrm{~km}^{2}$ is being developed about $10 \mathrm{~km}$ northeast of Kolkata.

The subsurface geology of the area consists of Quaternary fluviatile sediments comprising a succession of silty clay, sand and sand mixed with occasional gravel. In some places, along with silty clay, clayey silt and clay are also present at the upper part of the lithological column (Sikdar 2000; Sahu 2006; Sahu and Sikdar 2008, 2009a, b; Sikdar and Sahu 2009; Sahu et al. 2013). Deeper exploratory boreholes, drilled by various agencies suggest the existence of underlying tertiary clay/silty clay at an average depth of $300 \mathrm{~m}$ (Sikdar 2000; Sahu et al. 2013). This formation continues up to a depth of at least $614 \mathrm{~m}$ below the ground surface (Sahu and Sikdar 2008, 2011; Sikdar and Sahu 2009).

The Quaternary aquifer of the study area is sandwiched between two silty clay/clay sequences and is more or less continuous in nature. The upper aquitard consisting of silty clay, clayey silt and clay helps to hold water in the aquifer below, under pressure. Therefore, in the study area, groundwater generally occurs under confined condition. However, subsurface distribution of the upper confining lithological unit indicates that in the northern part of the study area and in few areas, around Kolkata, the thickness of the upper aquitard is $<10 \mathrm{~m}$ and at places it is absent. The areas where the aquitard is absent are the recharge areas through which direct infiltration of precipitation takes place into the aquifer and groundwater occurs under unconfined condition (Sahu and Sikdar 2011). Groundwater has been over-developed in and around Kolkata 


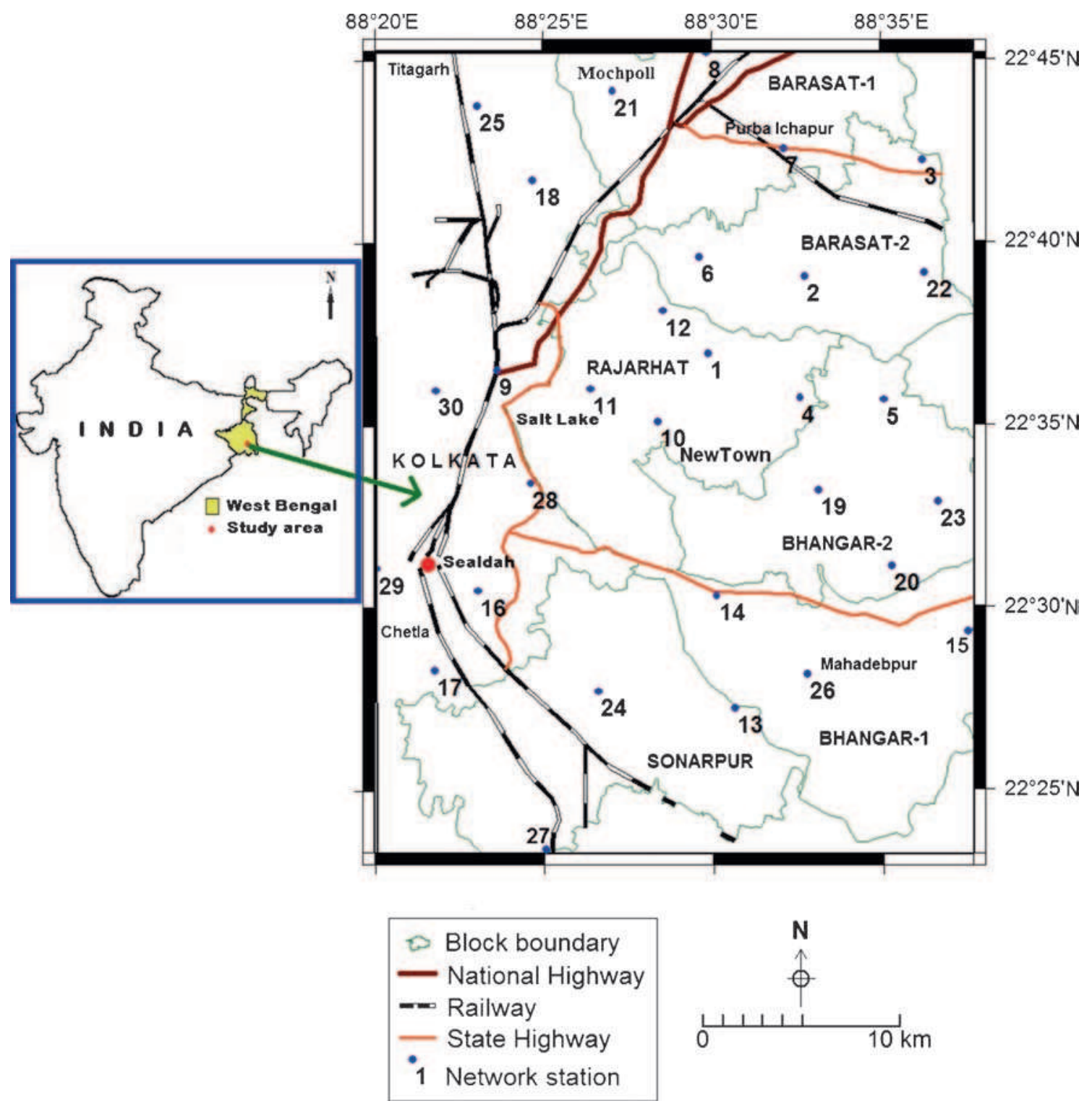

Figure 1. Location map of the study area.

city including Salt Lake city during the last six decades resulting in the lowering of the piezometric head by $5-16 \mathrm{~m}$. As a result, the groundwater flow pattern has also changed from an open natural north to south groundwater flow to a closed one, with the development of a major groundwater trough in east-central Kolkata (Sikdar et al. 2001). At present, more than $3 \times 10^{5} \mathrm{~m}^{3} /$ day of groundwater is being abstracted from the city aquifer. In RNT, the local authority has planned to install 74 deep tubewells to meet the drinking water requirement of the town. The rate of discharge of each well is $100 \mathrm{~m}^{3} / \mathrm{hr}$. This future groundwater abstraction may cause interference effect in wells in Kolkata and Salt Lake, lower the piezometric head and induce As-rich water present in the groundwater of Barasat, North 24 Parganas district (Sahu et al. 2013), located $20 \mathrm{~km}$ NNE of
Kolkata city to flow into the aquifers of RNT and Kolkata.

\section{Methods}

\subsection{Piezometric head}

Piezometric heads were measured in 30 water level monitoring stations in May and December 2011 using Solinst Model 101 water level meter. The water level monitoring stations were domestic wells fitted with hand pump. The latitude and longitude of each well were recorded in the field with a handheld GARMIN make 72H GPS, using WGS 84 as the reference datum. The mid-screen depth of the wells ranges from 91 to $305 \mathrm{~m}$. The elevation of the ground surface at the well points was extracted from the Shuttle Radar Topography 
Mission (SRTM) digital elevation data (EROS 2002) produced by NASA with a spatial resolution of $90 \mathrm{~m}$.

\subsection{Collection and analysis of groundwater samples}

Groundwater samples were collected from 30 wells in January 2012 for chemical analysis to ascertain their suitability for drinking. For As, an additional 350 wells were sampled and analyzed in the field, using a Wagtech digital arsenator. Its methodology is simple. Reagents reduce inorganic As in water to arsine gas, which reacts with mercuric bromide on a filter strip and turns it from white to different hues of yellow or brown, depending on the As concentration. The strip is then inserted in the arsenator, which calculates the precise concentration of As. It takes about 20 min to conduct the test. For detailed chemical analysis, the samples were collected in clean polyethylene bottles. Sampling bottles were soaked in 1:1 dilute $\mathrm{HCl}$ solution for $24 \mathrm{hrs}$, washed three times with deionized water, and washed again prior to each sampling, with the sample water. Wells were gently purged prior to collection of the sample. The depth of each well was recorded at the time of sampling by asking the owner how many pipes (including screen) were used during installation. During sampling, the samples were filtered with Whatman 40 filter paper. Immediately after sampling, the $\mathrm{pH}$ and As of the groundwater samples were measured in the field. $\mathrm{pH}$ was measured using $702 \mathrm{SM}$ Titrino $\mathrm{pH}$ meter (Swiss made). For As measurement, water samples drawn from wells were not filtered, unless visibly turbid to obtain an accurate measurement of the As concentration in water consumed by well-users, who do not filter their water. The samples were taken to the laboratory within $24 \mathrm{hrs}$ of collection and during transportation due care was taken to protect the water samples from direct sunlight. The parameters analyzed in the laboratory were total dissolved solid (TDS), total hardness $(\mathrm{TH})$, calcium (Ca), magnesium $(\mathrm{Mg})$, sodium $(\mathrm{Na})$, potassium $(\mathrm{K})$, bicarbonate $\left(\mathrm{HCO}_{3}\right)$, sulphate $\left(\mathrm{SO}_{4}\right)$, chloride $(\mathrm{Cl})$, phosphate $\left(\mathrm{PO}_{4}\right)$, nitrate $\left(\mathrm{NO}_{3}\right)$, fluoride $(\mathrm{F})$, iodide $(\mathrm{I})$, iron $(\mathrm{Fe})$, manganese $(\mathrm{Mn})$, zinc $(\mathrm{Zn})$, lead $(\mathrm{Pb})$ and cadmium (Cd). In the laboratory, the samples were filtered using $0.45 \mu \mathrm{m}$ Millipore filter paper and acidified with ultra-pure nitric acid for cation analysis. For anion analysis, the samples were refrigerated at $4^{\circ} \mathrm{C}$. The anions and cations in the groundwater samples were determined as per the standard procedures (APHA 1995). $\mathrm{HCO}_{3}$ was determined titrimetrically against standard hydrochloric acid $(0.01 \mathrm{~N})$. $\mathrm{Na}$ and $\mathrm{K}$ were analyzed using Flame photometer (Systronics FPM digital model). $\mathrm{Ca}$ and $\mathrm{Mg}$ were estimated by EDTA (0.01 M) titrimetric method, whereas $\mathrm{Cl}$ was determined by potentiometric titration using standard silver nitrate as reagent. F was measured using fluoride ionelectrode (ORION $720 \mathrm{~A}+$ ). $\mathrm{SO}_{4}$ was measured following the turbidity method using spectrophotometer. $\mathrm{NO}_{3}$ was determined by diazotization reaction method. $\mathrm{PO}_{4}$ was measured by $\mathrm{HNO}_{3}-$ $\mathrm{H}_{2} \mathrm{SO}_{4}$ digestion method using Milton-Ray Spectronic $20 \mathrm{D}^{+}$UV-VIS spectrophotometer. Fe was measured using Inductively Coupled Plasma-Mass Spectrometer (ICP-MS). Mn, Zn, Cr, Pb and $\mathrm{Cd}$ were determined by PG STAT Autolab-30 along with 663 VA Trace Analyzer (Metrohm made in Netherlands). The analytical precision for the measurement of ions was determined by calculating the ionic balance error, which is generally within $\pm 5 \%$.

The relevant chemical parameters of the groundwater samples have been plotted in the trilinear diagram of Piper (1944) using GW Chart software of USGS to delineate different hydrochemical facies (Back 1960; Ophori and Toth 1989) and in Gibbs diagram (Gibbs 1970) to understand the mechanisms controlling the chemistry of groundwater (Barnes et al. 2003; Rajmohan and Elango 2006; Sikdar and Chakraborty 2008).

\subsection{Water Quality Index}

Water Quality Index (WQI) is a rating reflecting the composite influence of different water quality parameters on the overall quality of water for human consumption (Tiwari and Mishra 1985; Singh 1992; Subba Rao 1997; Mishra and Patel 2001; Naik and Purohit 2001; Sahu and Sikdar 2008). For assessment of WQI, 16 parameters were selected which include $\mathrm{pH}$, TDS, TH, $\mathrm{HCO}_{3}, \mathrm{Cl}$, $\mathrm{SO}_{4}, \mathrm{NO}_{3}, \mathrm{~F}, \mathrm{Ca}, \mathrm{Mg}, \mathrm{Fe}, \mathrm{Mn}, \mathrm{As}, \mathrm{Zn}, \mathrm{Pb}$, and $\mathrm{Cd}$. In the formulation of WQI, the importance of various parameters depends on the intended use of water; here, water quality parameters are studied from the point of view of suitability for human consumption.WQI has been computed (Sahu and Sikdar 2008) as follows:

(i) A weight is allocated to each parameter (table 1) based on its relative importance as laid down in the Indian drinking water quality standard (BIS 10500 2003).

(ii) The relative weight of each parameter (table 1) is computed from the following equation:

$$
W_{i}=\frac{w_{i}}{\sum_{i=1}^{n} w_{i}}
$$

where $W_{i}=$ relative weight, $w_{i}=$ weight of each parameter, and $n=$ number of parameters. 
Table 1. Relative weight of chemical parameters.

\begin{tabular}{lccc}
\hline $\begin{array}{l}\text { Chemical } \\
\text { parameters }\end{array}$ & $\begin{array}{c}\text { Standards* } \\
\text { (BIS 10500 2003) }\end{array}$ & $\begin{array}{c}\text { Weight } \\
\left(w_{i}\right)\end{array}$ & $\begin{array}{c}\text { Relative } \\
\text { weight }\left(W_{i}\right)\end{array}$ \\
\hline pH & $6.5-8.5$ & 4 & 0.07018 \\
TDS & $500-2000$ & 4 & 0.07018 \\
Total hardness & $300-600$ & 2 & 0.03509 \\
Bicarbonate & $244-732$ & 3 & 0.05263 \\
Chloride & $250-1000$ & 3 & 0.05263 \\
Sulphate & $200-400$ & 4 & 0.07018 \\
Nitrate & $45-100$ & 5 & 0.08772 \\
Fluoride & $1-1.5$ & 4 & 0.07018 \\
Calcium & $75-200$ & 2 & 0.03509 \\
Magnesium & $30-100$ & 2 & 0.03509 \\
Iron & $0.3-1.0$ & 4 & 0.07018 \\
Manganese & $0.1-0.3$ & 4 & 0.07018 \\
Arsenic & $0.01-0.05$ & 5 & 0.08772 \\
Zinc & $5-15$ & 1 & 0.01754 \\
Lead & 0.05 & 5 & 0.08772 \\
Cadmium & 0.01 & 5 & 0.08772 \\
& & $\sum w_{i}=57$ & $\sum W_{i}=1.000$ \\
\hline
\end{tabular}

*For each parameter, lower value indicates desirable level and higher value indicates permissible level in absence of alternate source as per BIS 10500, 2003. All values are in $\mathrm{mg} / \mathrm{L}$ except $\mathrm{pH}$.

(iii) A quality rating scale $\left(q_{i}\right)$ for each parameter is assigned using equation (2)

$$
q_{i}=\left(\frac{C_{i}}{S_{i}}\right) \cdot 100
$$

where $q_{i}=$ quality rating, $C_{i}=$ concentration of each chemical parameter in each water sample in $\mathrm{mg} / \mathrm{L}, S_{i}=$ Indian drinking water standard for each chemical, parameter in $\mathrm{mg} / \mathrm{L}$, according to the guidelines of the BIS 10500, 2003.

(iv) The water quality index (WQI) is calculated using equations (3 and 4$)$

$$
\begin{gathered}
S I_{i}=W_{i} \cdot q_{i}, \\
\mathrm{WQI}=\sum_{i=1}^{n} S I_{i},
\end{gathered}
$$

where $S I_{i}=$ sub-index of ith parameter, $q_{i}=$ rating based on concentration of $i$ th parameter, and $n=$ number of parameters.

The computed WQI values are classified into the following three categories after Sahu and Sikdar (2008).

Excellent water $<50$

Good water $50-100$

Poor water $>100$

\subsection{Principal component analysis}

Varimax-rotated R-mode factor analysis or principal component analysis (PCA) was carried out to understand the compositional data structure and to separate and estimate the relative importance of the factors controlling the chemical evolution of groundwater (Usnoff and Guzman 1989; Sikdar et al. 1993, 2001; Ballukraya and Ravi 1999; Rao Lingeswara 2001; Sánchez-Martos et al. 2001; Hoon Kim et al. 2004; Kaplunovsky 2005; Mrklas et al. 2006; Saha et al. 2008; Sikdar and Chakraborty 2008) using SPSS v.10 software. Varimax rotation via the Kaiser normalization procedure has been used to calculate the rotated factor matrix. The rotation makes the factors easier to interpret by maximizing the differences between the variables (Lee et al. 2001; Invernizzi and de Oliveira 2004). Variables which exhibited a rotated loading $>0.5$ were considered significant. In this study, the first five factors of PCA are selected to represent the dominant hydrochemical processes, which have helped in the formation of the groundwater chemistry without losing significant information. Plots of factor scores have been used to relate the intensity of the chemical process described by each factor (Dalton and Upchurch 1978; Lawrence and Upchurch 1982).

\section{Results and discussion}

\subsection{Piezometric head}

Summary of piezometric surface data is presented in table 2. The piezometric surface at places rests at a depth below the MSL. Piezometric surface contour maps for May (pre-monsoon), 2011 (figure 2a) and December (post-monsoon), 2011 (figure 2b) reveal that in both the periods, a major groundwater trough has developed in the west-central part of the study area, in and around Beleghata of Kolkata city. A prominent groundwater mound has formed in the northeast, in and around Titagarh and there is a tendency of the formation of new mounds in the northeast and east. During premonsoon period, a local groundwater trough has formed adjacent to the mound around Titagarh. The formation of groundwater troughs and mounds is due to variability in groundwater abstraction as a result of supply of treated surface water by government agencies. The regional groundwater flow of the area including pollutant transport is controlled by the major trough and groundwater flows towards this trough from the surrounding regions.

\subsection{Groundwater quality}

The result of the chemical analyses of groundwater from the study area is summarized in table 3 . 
Table 2. Summary of piezometric surface data of the study area.

\begin{tabular}{|c|c|c|c|c|c|c|c|}
\hline \multirow[b]{2}{*}{ Period } & \multicolumn{3}{|c|}{ Depth to piezometric surface level (m) } & \multicolumn{4}{|c|}{$\begin{array}{l}\text { Piezometric surface level with respect to } \\
\text { mean sea level }(\mathrm{m})\end{array}$} \\
\hline & $\begin{array}{l}\text { Minimum } \\
\quad(\mathrm{m})\end{array}$ & $\begin{array}{l}\text { Maximum } \\
\quad(\mathrm{m})\end{array}$ & $\begin{array}{l}\text { Mean } \\
(\mathrm{m})\end{array}$ & $\begin{array}{l}\text { Minimum } \\
\quad(\mathrm{m})\end{array}$ & $\begin{array}{l}\text { Maximum } \\
\quad(\mathrm{m})\end{array}$ & $\begin{array}{c}\text { Mean } \\
(\mathrm{m})\end{array}$ & $\begin{array}{c}\text { Standard } \\
\text { deviation }(\mathrm{m})\end{array}$ \\
\hline $\begin{array}{l}\text { May (pre-monsoon), } \\
2011\end{array}$ & 2.64 & 17.1 & 8.75 & -12.3 & 9.46 & -2.78 & 5.11 \\
\hline $\begin{array}{l}\text { December (post- } \\
\text { monsoon), } 2011\end{array}$ & 1.66 & 15.9 & 7.05 & -11.4 & 10.4 & -1.08 & 5.09 \\
\hline
\end{tabular}
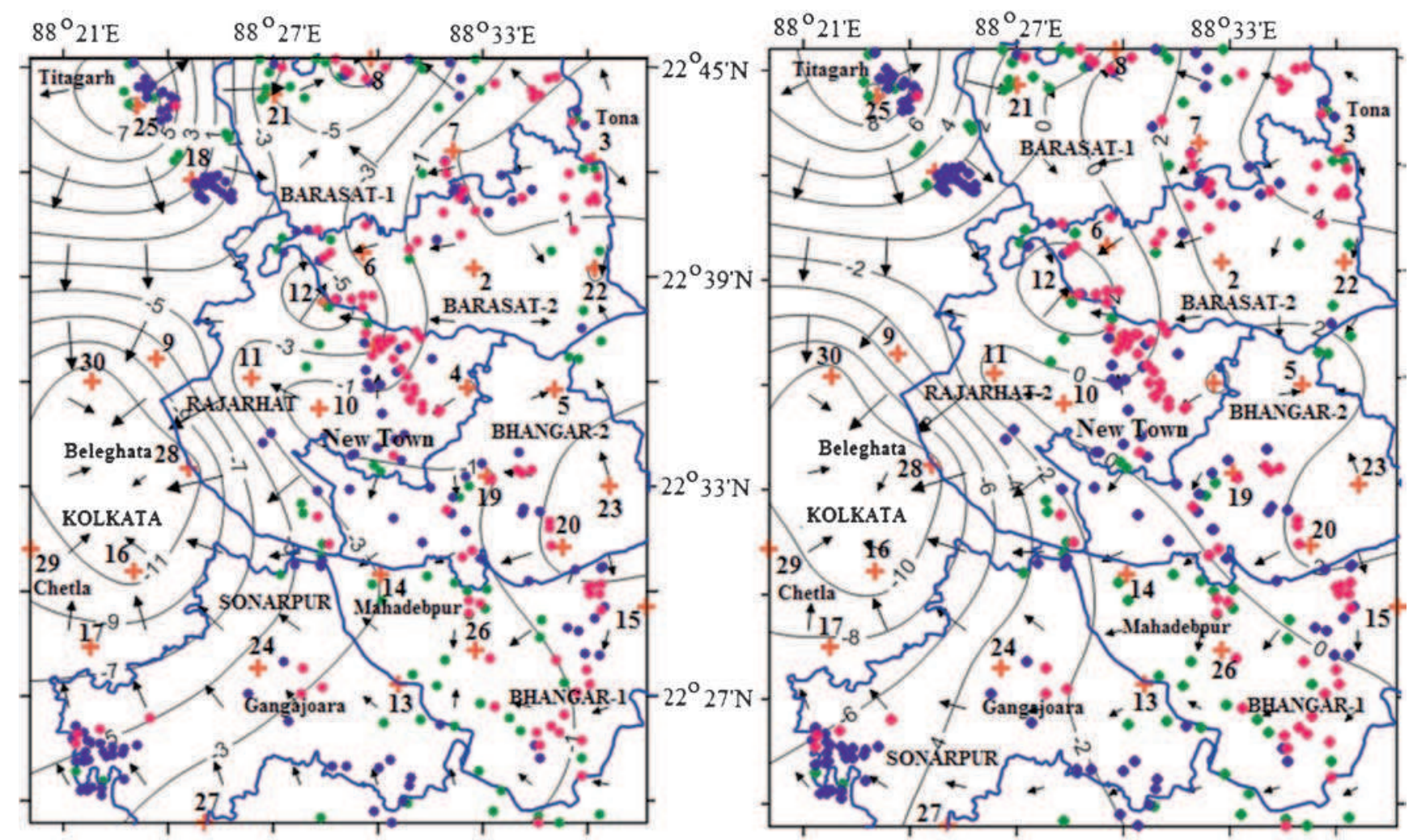

\begin{tabular}{|ll|}
\hline 11 Network Station & As concentration in wells \\
G Groundwater flow direction & $->50 \mathrm{ppb}$ \\
Piezometric surface contour & $-10-50 \mathrm{ppb}$ \\
Block boundary & $-<10 \mathrm{ppb}$ \\
\hline
\end{tabular}

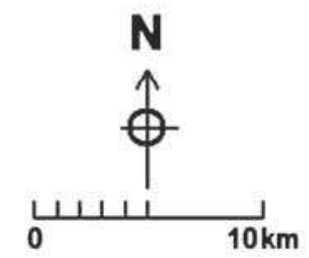

Figure 2. Piezometric surface elevation contour map of (a) pre-monsoon and (b) post-monsoon periods showing groundwater flow direction along with arsenic concentration.

\subsubsection{As distribution}

Detailed hydrogeological work with respect to As distribution was carried out in the northeastern part of the area (McArthur et al. 2004, 2008, 2010, 2011, 2012a, b; Hoque et al. 2012; Sikdar et al. 2013). The upper part of the subsurface sedimentary sequence of the area consists of post-Last Glacial Maximum (LGM) clay, silt, fine sand and peat of about $20 \mathrm{~m}$ thickness, which is the upper aquitard. This is followed downward by a shallow aquifer, a clay aquiclude, a deep aquifer and a basal aquiclude. The shallow aquifer comprises two types of lithological sequences: (1) palaeo-channel sequence and (2) palaeo-interfluve sequence. In the palaeo-channel sequence, the post-LGM sediments are floored by pre-LGM grey and reduced channel sands and Late Pleistocene brown and oxidized sands. These two sandy units are in hydraulic continuity. In the palaeo-interfluve sequence, the 
Table 3. Chemical composition of groundwater of the area in and around Rajarhat.

\begin{tabular}{llll}
\hline & & \multicolumn{2}{l}{ Concentration } \\
\cline { 2 - 4 } Parameter & Max. & Min. & Avg. \\
\hline pH & 8.5 & 8.21 & 8.41 \\
TDS & 1117 & 266 & 632 \\
Total hardness & 446 & 26 & 161 \\
Calcium & 80 & 5 & 27 \\
Magnesium & 62 & 3 & 23 \\
Sodium & 163 & 58 & 112 \\
Potassium & 6 & 2 & 4 \\
Bicarbonate & 524 & 76 & 332 \\
Sulphate & 6 & 1 & 4 \\
Phosphate & 2 & 1 & 2 \\
Nitrate & 1 & 0.2 & 0.5 \\
Chloride & 356 & 11 & 91 \\
Iodide & 210 & 0 & 41 \\
Fluoride & 0.4 & 0.1 & 0.2 \\
Iron & 4.7 & 0.3 & 0.9 \\
Manganese & 1.54 & 0.003 & 0.20 \\
Arsenic & 0.082 & 0 & 0.004 \\
Zinc & 2.72 & 0 & 0.27 \\
Lead & 0.02 & 0 & 0.005 \\
Cadmium & 0.008 & 0.001 & 0.002 \\
\hline
\end{tabular}

All values are in mg/L except $\mathrm{As}(\mu \mathrm{g} / \mathrm{L})$ and $\mathrm{pH}$.

post-LGM sediments are floored by Late Pleistocene brown and oxidized sands capped by impermeable LGM reddish brown stiff hard clay containing carbonized rootlets (palaeosol) at depth interval of $18-23 \mathrm{~m}$. Both these sequences are followed by a $30-\mathrm{m}$ thick aquiclude at depth interval of 46-76 m. This aquiclude is made of soft, grey clay containing some wood fragments at the top followed by slightly harder grey clay. This aquiclude is floored by a $122-\mathrm{m}$ thick aquifer of grey sand (deep aquifer). Deeper lithological logs of the area reveal the presence of thick continuous clay below the deep aquifer between 198 and $308 \mathrm{~m}$ (Sikdar et al. 2013).

Groundwater from aquifers which comprised brown sand below the LGM palaeosol was free of As-pollution (McArthur et al. 2004, 2008, 2011; Sikdar et al. 2013) due to the sorptive capacity of As by the Fe-oxyhydroxides they contain. Groundwater from shallow grey sands are Aspolluted because the original Fe-oxyhydroxide has been completely reduced and its sorbed As has been released to solution (McArthur et al. 2004, 2008, 2011). The distribution of brown and grey sands, and so the distribution of As-pollution, may reflect the distribution of subsurface palaeointerfluves and palaeo-channels (McArthur et al. 2008,2011 ) that formed an ancient, now buried landscape, sculpted when sea level was lower than it is today (Umitsu 1987, 1993).
Table 4. Water quality index and groundwater types.

\begin{tabular}{lrl}
\hline & WQI $=\sum_{i=1}^{n} S I_{i}$ & \\
\hline 1 & 46 & Water type \\
2 & 66 & Excellent water \\
3 & 51 & Good water \\
4 & 63 & Good water \\
5 & 71 & Good water \\
6 & 100 & Good water \\
7 & 48 & Excellent water \\
8 & 120 & Poor water \\
9 & 46 & Excellent water \\
10 & 62 & Good water \\
11 & 56 & Good water \\
12 & 46 & Excellent water \\
13 & 96 & Good water \\
14 & 44 & Excellent water \\
15 & 56 & Good water \\
16 & 79 & Good water \\
17 & 60 & Good water \\
18 & 40 & Excellent water \\
19 & 194 & Poor water \\
20 & 100 & Good water \\
21 & 78 & Good water \\
22 & 143 & Poor water \\
23 & 88 & Good water \\
24 & 64 & Good water \\
25 & 51 & Good water \\
26 & 81 & Good water \\
27 & 41 & Excellent water \\
28 & 99 & Good water \\
29 & 48 & Excellent water \\
30 & 135 & Poor water \\
\hline & &
\end{tabular}

High As $(>10 \mu \mathrm{g} / \mathrm{L})$ in groundwater is observed mainly in the eastern, northeastern and southeastern parts of the study area (figure $2 \mathrm{a}$ and b). High As is found in the groundwater below New Town and also in the adjacent areas in the north and southeast. Groundwater from the Asrich part of the aquifer flows towards the wells in New Town both during pre-monsoon and postmonsoon periods (figure $2 \mathrm{a}$ and $\mathrm{b}$ ). Therefore, New Town's aquifer is vulnerable to As-pollution under the present pumping scenario. The vulnerability may increase with additional pumping in the future.

\subsubsection{Water Quality Index (WQI)}

The computed WQI values range from 40 to 194 and can be categorized into three types, 'excellent water', 'good water' and 'poor water' (table 4). Majority of the samples, about $60 \%$, falls in the 

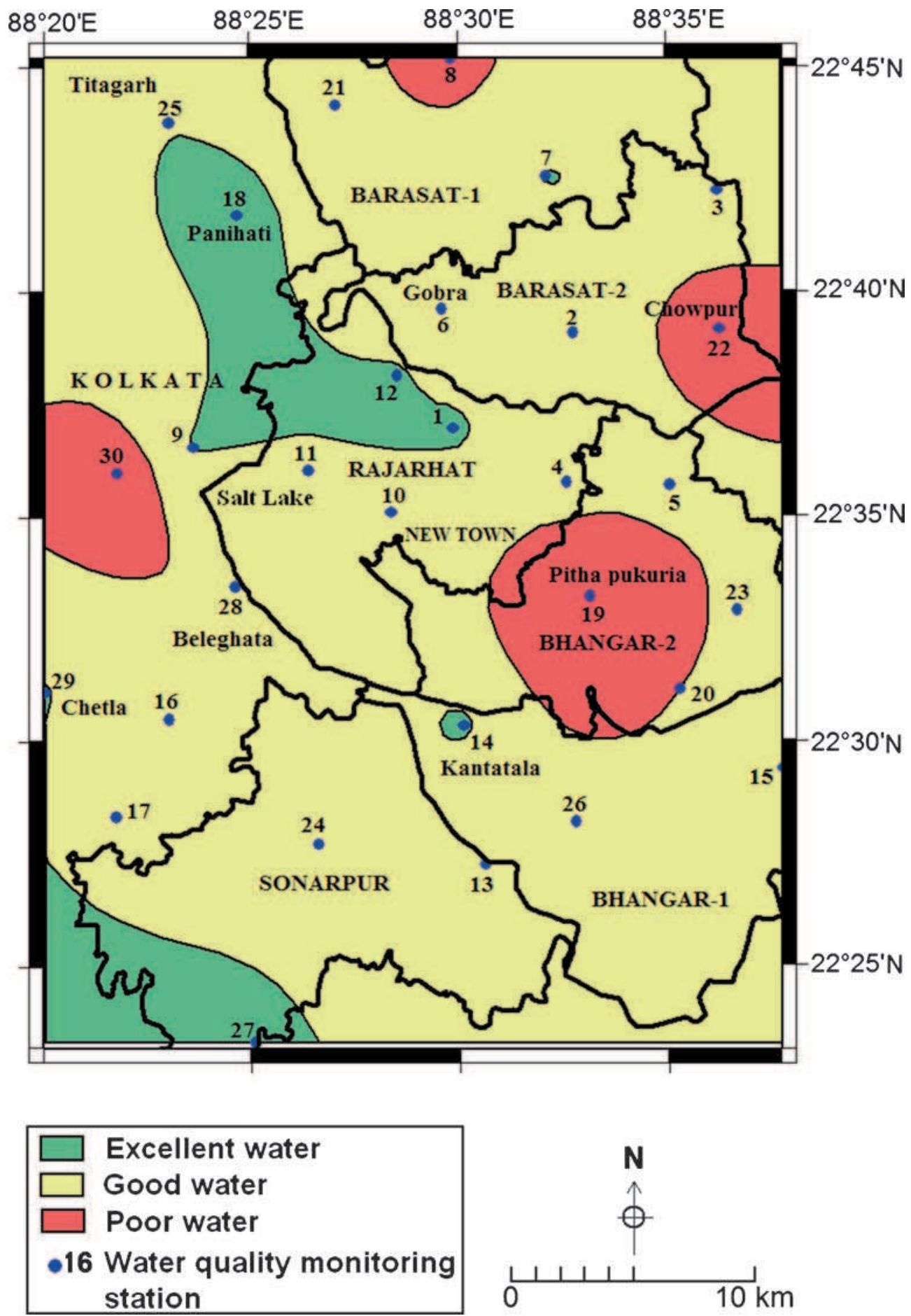

Figure 3. Spatial distribution of the water types based on WQI of the area in and around Rajarhat.

category of 'good water'. 'Excellent water' is about $27 \%$ and the rest is 'poor water'. The spatial distribution of the water types is shown in figure 3 . The spatial variation in the WQI is mostly due to the concentration variation of $\mathrm{Fe}, \mathrm{As}$ and $\mathrm{Cl}$ in groundwater. As and $\mathrm{Fe}$ have been released due to microbial reduction of sedimentary Fe(III)oxyhydroxides, when $\mathrm{As}(\mathrm{V})$ is reduced to $\mathrm{As}(\mathrm{III})$. High $\mathrm{Cl}$ possibly derives from marine salt (mostly mixing of saline connate water) as discussed in later sections.

\subsubsection{Hydrochemical facies}

Based on the plots of major cations $\left(\mathrm{Ca}^{2+}, \mathrm{Mg}^{2+}\right.$, $\mathrm{Na}^{+}$and $\left.\mathrm{K}^{+}\right)$and major anions $\left(\mathrm{Cl}^{-}, \mathrm{HCO}_{3}^{-}\right.$and $\mathrm{SO}_{4}^{2-}$ ) content in the groundwater samples in the 


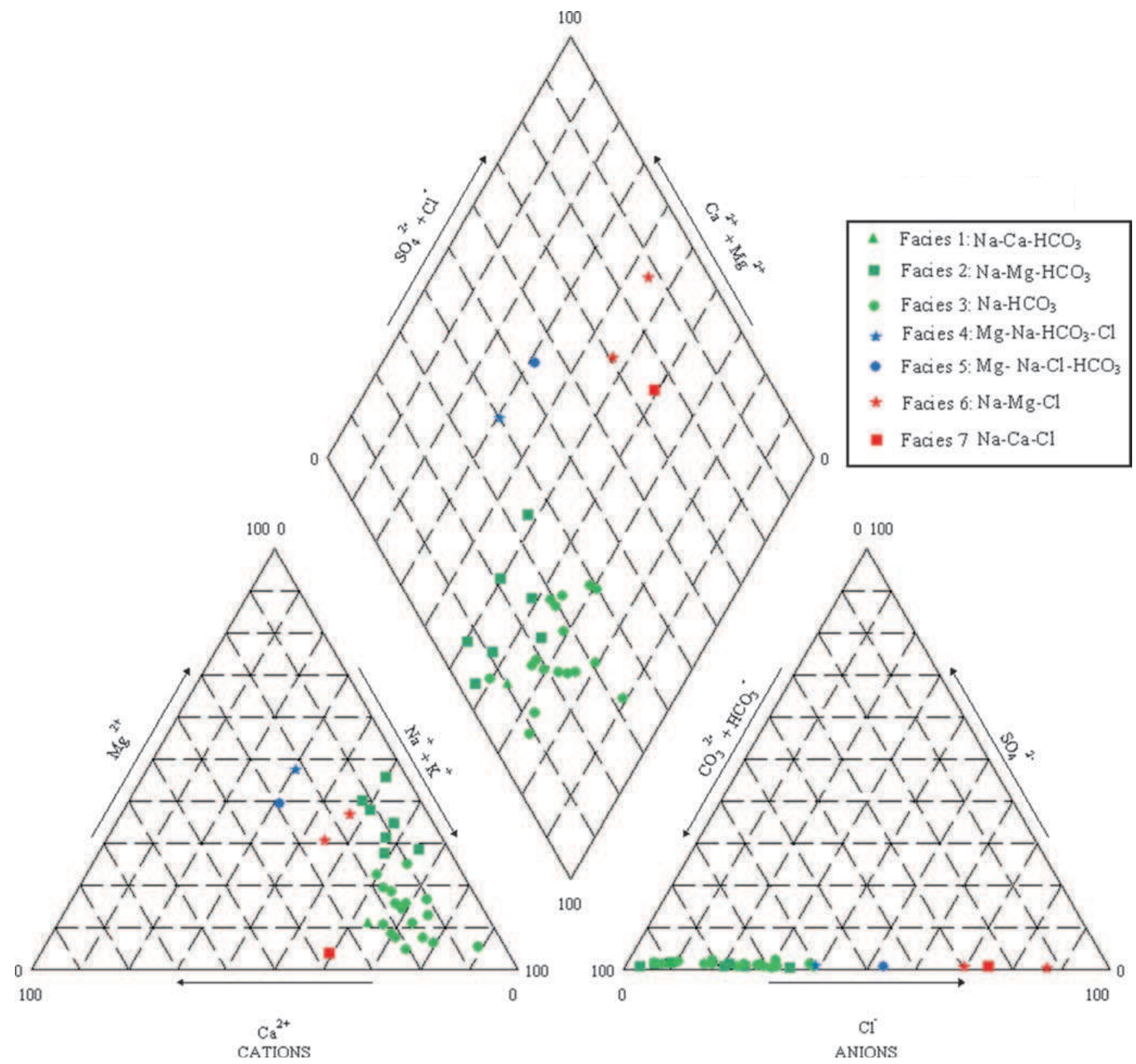

Figure 4. Piper diagram showing fields of different hydrochemical facies.

Piper's trilinear diagram (figure 4), seven hydrochemical facies have been identified. They are Facies 1: $\mathrm{Na}-\mathrm{Ca}-\mathrm{HCO}_{3}$; Facies 2: $\mathrm{Na}-\mathrm{Mg}-\mathrm{HCO}_{3}$; Facies 3: $\mathrm{Na}-\mathrm{HCO}_{3}$; Facies 4: $\mathrm{Mg}-\mathrm{Na}-\mathrm{HCO}_{3}-\mathrm{Cl}$; Facies 5: $\mathrm{Mg}-\mathrm{Na}-\mathrm{Cl}-\mathrm{HCO}_{3}$; Facies 6: $\mathrm{Na}-\mathrm{Mg}-\mathrm{Cl}$; and Facies $7 \mathrm{Na}-\mathrm{Ca}-\mathrm{Cl}$. The relevant chemical parameters of these facies are given in table 5 . The aerial distribution of these hydrochemical facies is depicted in figure 5.

These seven hydrochemical facies may be clubbed into three broad types - 'fresh', 'mixed', and 'brackish' waters based on the concentration of chloride and bicarbonate in the groundwater samples. The salient chemical properties of these water types are given in table 5 .
Fresh water. The 'fresh' groundwater consists of Facies 1, 2 and 3 and occupies $1003.5 \mathrm{~km}^{2}$ of area. The water is relatively soft with an average hardness of $133 \mathrm{mg} / \mathrm{L}$. This type of water is relatively fresh with TDS ranging between 266 and 921 $\mathrm{mg} / \mathrm{L}$ with an average of $567 \mathrm{mg} / \mathrm{L}$. The average $\mathrm{HCO}_{3}$ content $(352 \mathrm{mg} / \mathrm{L})$ far exceeds the average $\mathrm{Cl}$ content $(56 \mathrm{mg} / \mathrm{L})$.

Mixed water. The water belonging to this type comprises Facies 4 and 5 and occupies $195.1 \mathrm{~km}^{2}$ of area and is inferior in quality compared to the fresh water type. The water is hard with an average hardness of $374 \mathrm{mg} / \mathrm{L}$. The TDS concentration ranges from 696 to $1117 \mathrm{mg} / \mathrm{L}$ with an average 
of $907 \mathrm{mg} / \mathrm{L}$. The average $\mathrm{HCO}_{3}$ and $\mathrm{Cl}$ content of this type of water is $308 \mathrm{mg} / \mathrm{L}$ and $168 \mathrm{mg} / \mathrm{L}$, respectively.

Brackish water. Groundwater of Facies 6 and 7 belongs to 'brackish' type and occupies $24.4 \mathrm{~km}^{2}$ of area. The TDS concentration is high ranging from 720 to $1053 \mathrm{mg} / \mathrm{L}$, with an average of 921 $\mathrm{mg} / \mathrm{L}$. Average $\mathrm{Cl}$ content $(336 \mathrm{mg} / \mathrm{L})$ is also high with respect to average $\mathrm{HCO}_{3}$ concentration (179 $\mathrm{mg} / \mathrm{L}$ ). Though brackish, this water is not very hard and has a mean hardness of $255 \mathrm{mg} / \mathrm{L}$.

\subsubsection{Factors governing water chemistry}

The mechanism controlling water chemistry and the functional sources of dissolved ions have been assessed by plotting the ratios of $(\mathrm{Na}+\mathrm{K}) /(\mathrm{Na}+$ $\mathrm{K}+\mathrm{Ca})$ and $\mathrm{Cl} /\left(\mathrm{Cl}+\mathrm{HCO}_{3}\right)$ as functions of TDS and principal component analysis (PCA). Gibbs diagram of the water samples (figure 6) shows that enrichment of the major ions in groundwater is due to weathering of rock-forming minerals.

The output of the PCA (table 6) reveals that the first five eigen values together account for over $76 \%$ of the total variability of the combined population. The first principal component (PC1), which accounts for more than $21 \%$ of the total variance, has significant loading on $\mathrm{Cl}$ and $\mathrm{Ca}$ and moderately on $\mathrm{HCO}_{3}$. High loading on $\mathrm{Cl}$ indicates a relatively long residence time of the groundwater in the (i) zone of stagnation and/or sluggish movement of groundwater due to the presence of low permeable material and (ii) groundwater trough. High loading on Ca indicates the influence of weathering of minerals such as calcite, feldspar, garnet, hornblende, tourmaline and amphibole present in the aquifer matrix (Datta and Subramanian 1997; Sikdar and
Banerjee 2003). PC1 also points towards possible occurrence of $\mathrm{Ca}$ as $\mathrm{CaCl}_{2}$ which imparts permanent hardness to groundwater. High loading on TDS indicates that the dissolved solid in groundwater is mainly dominated by $\mathrm{Ca}$ and $\mathrm{Cl}$. The second principal component (PC2) has high loadings on $\mathrm{Mg}, \mathrm{K}, \mathrm{Mn}$ and TDS, and contributes more than $20 \%$ of the total variance. Both $\mathrm{Mg}$ and $\mathrm{K}$ indicate the influence of weathering of ferromagnesian and feldspathic minerals respectively. High loading on $\mathrm{K}$ may indicate the process of weathering of orthoclase, microcline feldspar, biotite and muscovite present in the sediment (Sikdar and Banerjee 2003), which releases K to groundwater. High loading on $\mathrm{Mn}$ reveals that the process of reduction of manganese oxide by microbes is active in the study area (McArthur et al. 2012b). High loading on TDS indicates dissolved solids in groundwater are also moderately dominated by $\mathrm{Mg}, \mathrm{K}$ and $\mathrm{Mn}$.

The third principal component (PC3) and the fourth principal component (PC4) have high loadings on $\mathrm{Na}$ and $\mathrm{HCO}_{3}, \mathrm{SO}_{4}$ and $\mathrm{NO}_{3}$ respectively, and both components have moderate loading on $\mathrm{Fe}$. Presence of $\mathrm{Na}$ in groundwater indicates the influence of weathering of sodium bearing feldspathic minerals such as albite present in the aquifer matrix. High loading on $\mathrm{HCO}_{3}$ can be attributed to $\mathrm{CO}_{2}$ present in rainwater and soil. Oxidation of organic matter by microbes also generates $\mathrm{CO}_{2}$ which then combines with water to form carbonic acid which further dissociates to $\mathrm{H}^{+}$and $\mathrm{HCO}_{3}^{-}$, as per the following equations:

$$
\begin{gathered}
\mathrm{CO}_{2}+\mathrm{H}_{2} \mathrm{O} \leftrightarrow \mathrm{H}_{2} \mathrm{CO}_{3}, \\
\mathrm{H}_{2} \mathrm{CO}_{3} \leftrightarrow \mathrm{H}^{+}+\mathrm{HCO}_{3}^{-} .
\end{gathered}
$$

\begin{tabular}{|c|c|c|c|c|c|c|c|}
\hline \multirow[b]{2}{*}{ Facies type } & \multicolumn{4}{|c|}{ Cation (\% equivalent) } & \multicolumn{3}{|c|}{ Anion ( $\%$ equivalent) } \\
\hline & $\mathrm{Ca}^{++}$ & $\mathrm{Mg}^{++}$ & $\mathrm{Na}^{+}$ & $\mathrm{K}^{+}$ & $\mathrm{Cl}^{-}$ & $\mathrm{HCO}_{3}^{-}$ & $\mathrm{SO}_{4}^{-}$ \\
\hline $\begin{array}{l}\text { Fresh water } \\
\text { Facies 1: } \mathrm{Na}-\mathrm{Ca}-\mathrm{HCO}_{3} \\
\text { Facies 2: } \mathrm{Na}-\mathrm{Mg}-\mathrm{HCO}_{3} \\
\text { Facies 3: } \mathrm{Na}-\mathrm{HCO}_{3}\end{array}$ & 14.5 & 19.1 & 65.0 & 1.34 & 21.0 & 77.9 & 1.1 \\
\hline $\begin{array}{l}\text { Mixed water } \\
\text { Facies 4: } \mathrm{Mg}-\mathrm{Na}-\mathrm{HCO}_{3}-\mathrm{Cl} \\
\text { Facies } 5: \mathrm{Mg}-\mathrm{Na}-\mathrm{Cl}-\mathrm{HCO}_{3}\end{array}$ & 25.6 & 43.4 & 29.6 & 1.4 & 46.1 & 53.1 & 0.8 \\
\hline $\begin{array}{l}\text { Brackish water } \\
\text { Facies 6: } \mathrm{Na}-\mathrm{Mg}-\mathrm{Cl} \\
\text { Facies } 7: \mathrm{Na}-\mathrm{Ca}-\mathrm{Cl}\end{array}$ & 25.8 & 23.8 & 49.3 & 1.1 & 77.1 & 22.4 & 0.5 \\
\hline
\end{tabular}

Table 5. Average composition of different hydrochemical facies. 

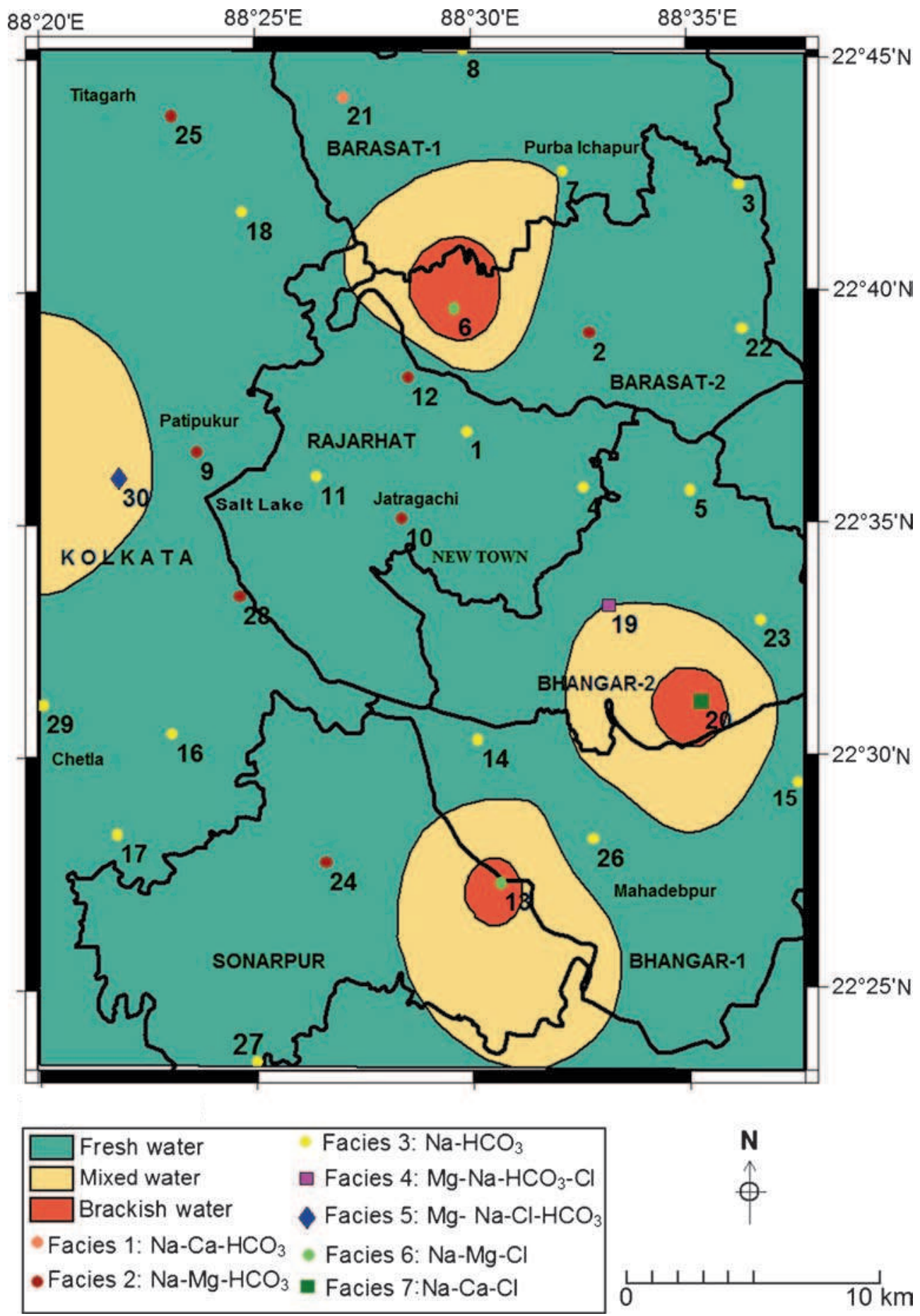

Figure 5. Spatial distribution of hydrochemical facies of the area in and around Rajarhat.

Presence of $\mathrm{NO}_{3}$ and excess $\mathrm{SO}_{4}$ (calculated as measured $\mathrm{SO}_{4} 2700 * \mathrm{Cl} / 19400$ and is the $\mathrm{SO}_{4}$ in excess of that derived from sea-salt) in groundwater (McArthur et al. 2012a) possibly indicates contamination of groundwater of the study area by wastewater. Presence of $\mathrm{Fe}$ in groundwater reveals that the process of reduction of $\mathrm{FeOOH}$ by microbes (McArthur et al. 2011) is active in the study area. High Fe in groundwater can also be contributed to weathering of Fe-bearing minerals such as illite, chlorite, biotite, garnet, hornblende, staurolite, tourmaline and amphibole present in the aquifer matrix (Sikdar and Banerjee 2003) and dissolution of iron pipes and hand-pump components of wells.

The fifth principal component (PC5) shows high loading on As. High As in groundwater is a result of microbial metabolism of organic carbon which 


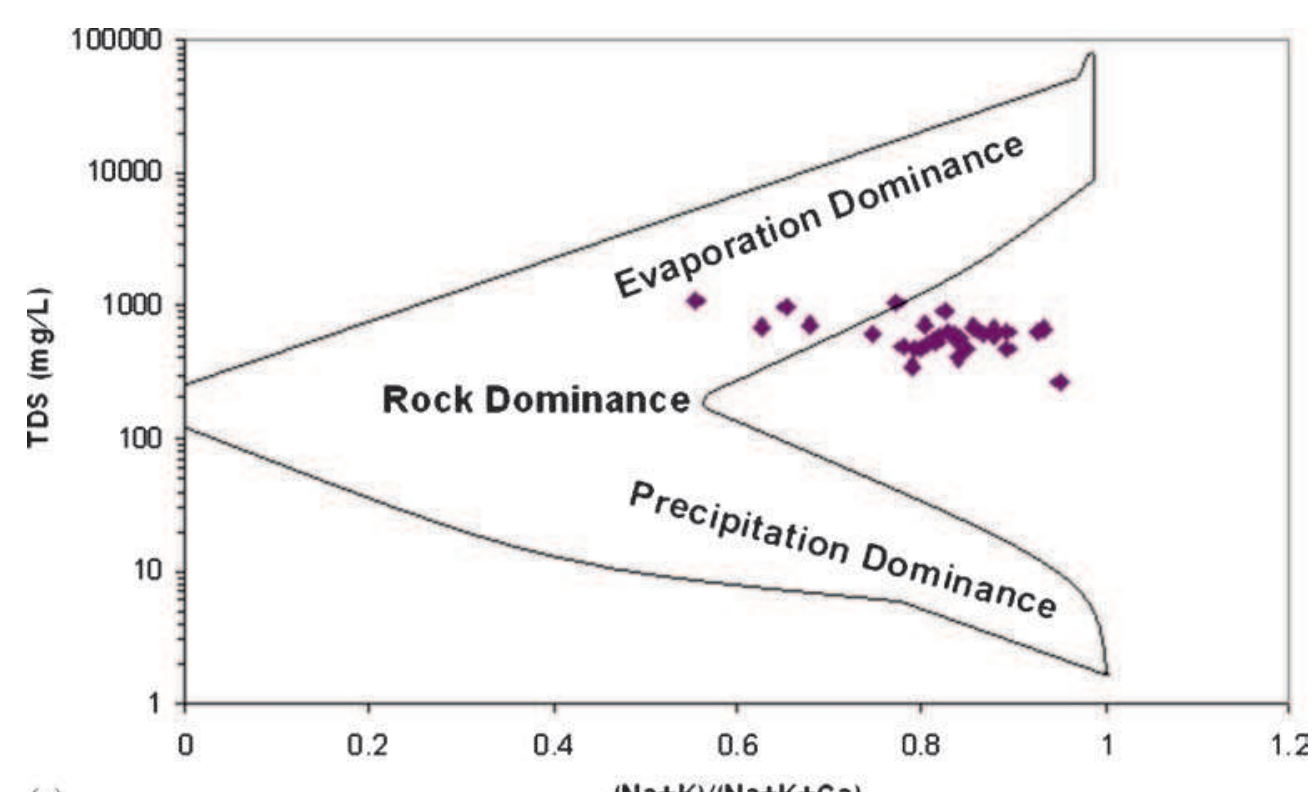

(a)

$(\mathrm{Na}+\mathrm{K}) /(\mathrm{Na}+\mathrm{K}+\mathrm{Ca})$

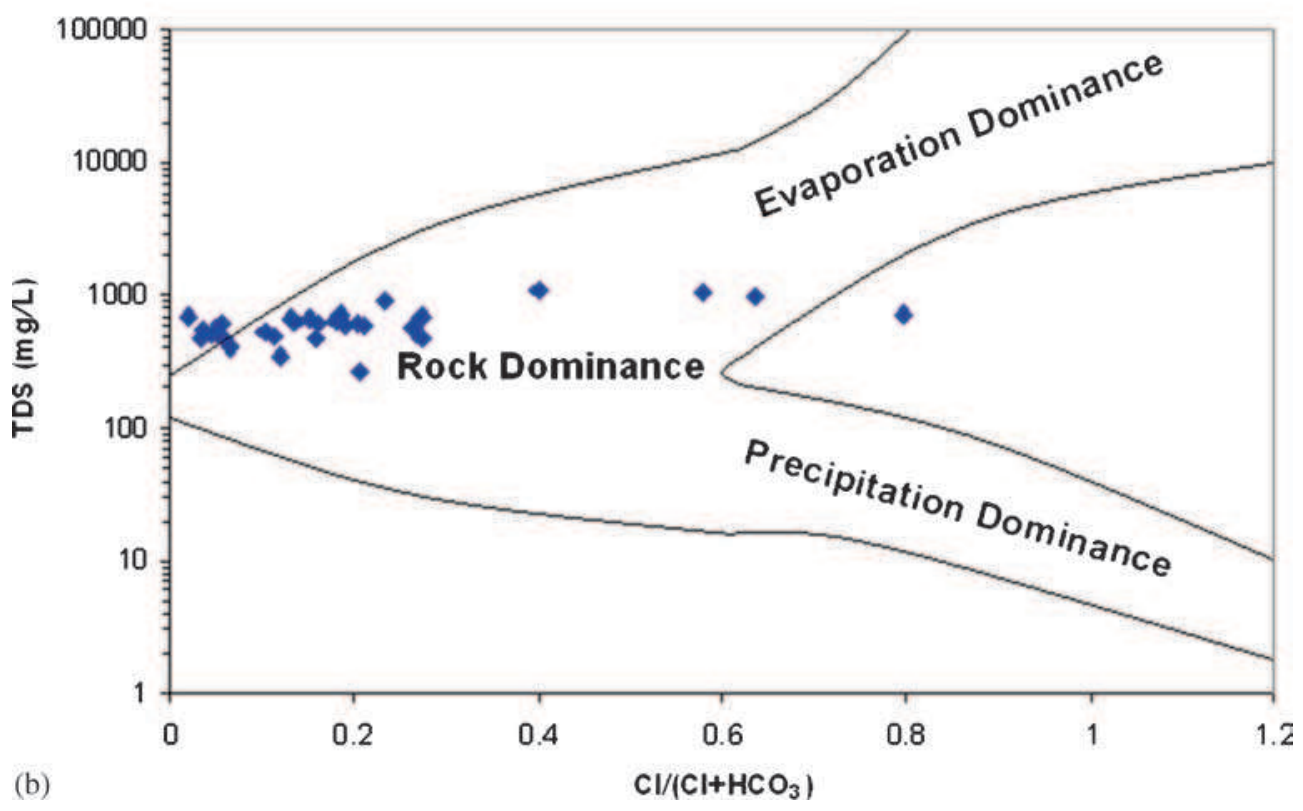

Figure 6. Scatter plots of $(\mathbf{a})(\mathrm{Na}+\mathrm{K}) /(\mathrm{Na}+\mathrm{K}+\mathrm{Ca})$ vs. TDS and $(\mathbf{b}) \mathrm{Cl} /\left(\mathrm{Cl}+\mathrm{HCO}_{3}\right)$ vs. TDS showing the mechanisms controlling the groundwater chemistry.

drives reduction of $\mathrm{FeOOH}$ and releases adsorbed As (McArthur et al. 2011).

The plots of PC-scores corresponding to PCaxis 1 ( $\mathrm{Cl}, \mathrm{Ca}$ and TDS dependent) and $\mathrm{PC}$-axis 3 (Na and $\mathrm{HCO}_{3}$-dependent) (which together account for about $36 \%$ of the total variability) are shown in figure 7. A clear categorization of data could be made in this diagram namely 'fresh', 'mixed' and 'brackish' types. The 'mixed' water occupies an intermediate position between the 'fresh' water and 'brackish' water. The aerial distribution (figure 5) of groundwater types also indicates that large pockets of 'mixed' water lie within the 'fresh' and 'brackish' water zones.

\subsection{Evolution of groundwater types}

The study area was below the sea level under a marine environment during the late Quaternary period (Sen and Banerjee 1990; Barui and Chanda 1992; Hait et al. 1994a, b; Sikdar et al. 2001). Later during regression of the sea, some seawater was trapped within the depositing sediments forming connate water and during its confinement was subjected to chemical alteration and formed modified connate water (Sikdar et al. 2001). This water rich in $\mathrm{Cl}$ has been progressively diluted by influxes of fresh water to form the present brackish water. Only 5 of our 30 well waters fall into the field 
Table 6. Principal component analysis of groundwater samples.

\begin{tabular}{lrrrrr}
\hline & \multicolumn{5}{c}{ Loading on PC axes } \\
\cline { 2 - 6 } Variables & PC1 & PC2 & PC3 & PC4 & PC5 \\
\hline $\mathrm{Cl}$ & $* 0.911$ & 0.203 & 0.059 & -0.136 & 0.013 \\
$\mathrm{SO}_{4}$ & -0.269 & -0.039 & -0.120 & $* 0.732$ & 0.293 \\
$\mathrm{HCO}_{3}$ & -0.516 & 0.360 & $* 0.608$ & 0.205 & 0.095 \\
$\mathrm{NO}_{3}$ & 0.068 & 0.010 & 0.124 & $* 0.699$ & -0.312 \\
$\mathrm{Na}$ & 0.189 & -0.124 & $* 0.902$ & 0.077 & -0.134 \\
$\mathrm{~K}$ & 0.169 & $* 0.749$ & 0.205 & 0.277 & -0.175 \\
$\mathrm{Ca}$ & $* 0.874$ & 0.241 & -0.045 & 0.063 & 0.042 \\
$\mathrm{Mg}$ & 0.117 & $* 0.858$ & -0.064 & -0.149 & -0.038 \\
$\mathrm{As}$ & 0.058 & -0.134 & 0.002 & -0.058 & $* 0.924$ \\
$\mathrm{Mn}$ & 0.275 & $* 0.679$ & -0.347 & -0.031 & -0.036 \\
$\mathrm{Fe}$ & 0.017 & 0.022 & -0.541 & 0.423 & -0.108 \\
$\mathrm{TDS}$ & $* 0.667$ & $* 0.618$ & 0.268 & -0.101 & -0.020 \\
$\%$ Eigen value & 21.160 & 20.038 & 14.577 & 11.559 & 9.262 \\
Cumulative \% & 21.160 & 41.198 & 55.775 & 67.334 & 76.596 \\
\hline
\end{tabular}

*Variables with significant loading.

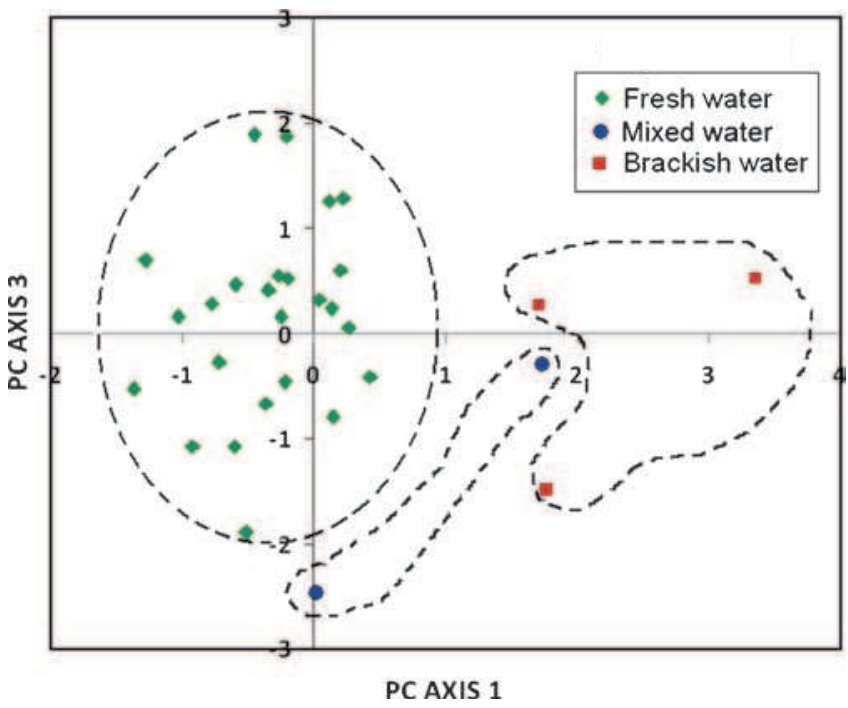

Figure 7. Plots of PC scores for PC1 vs. PC3.

of salinisation, indicating the freshening of modified connate water (figure $8 \mathrm{a}$ and $\mathrm{b}$ ). Well waters plotting close to the mixing line for seawater indicate late stage of aquifer flushing by freshwater (figure $8 \mathrm{a}$ and $\mathrm{b}$ ).

Fresh water facies are $\mathrm{Na}$ dominated, viz., Facies 1: $\mathrm{Na}-\mathrm{Ca}-\mathrm{HCO}_{3}$, Facies 2: $\mathrm{Na}-\mathrm{Mg}-\mathrm{HCO}_{3}$, and Facies 3: $\mathrm{Na}-\mathrm{HCO}_{3}$. Presence of these hydrochemical facies indicate active flushing of the aquifer by fresh water. These groundwaters also fall into the field of 'freshwater flushing' (figure 8a), indicating the recent history of the aquifer involving ion exchange of $\mathrm{Na}$ in aquifer material for $\mathrm{Ca}$ and $\mathrm{Mg}$ in groundwater. Presence of $\mathrm{Na}-\mathrm{HCO}_{3}$ in groundwater indicates that complete replacement of $\mathrm{Ca}$ and $\mathrm{Mg}$ of groundwater has taken place by $\mathrm{Na}$ in aquifer material. Hence, ion exchange of $\mathrm{Na}$ in aquifer material for $\mathrm{Ca}$ and $\mathrm{Mg}$ in water by circulating water in the present study area as per the following equation is very high:

$$
\begin{aligned}
& \mathrm{Ca}^{+2}+\mathrm{Mg}^{+2}(\text { water })+\mathrm{Na}_{2}-\text { clay } \\
& \left.\rightleftharpoons \mathrm{Ca}+\mathrm{Mg}-\text { clay }+2 \mathrm{Na}^{+} \text {(water }\right) .
\end{aligned}
$$

'Mixed' water consists of Facies 4: $\mathrm{Mg}-\mathrm{Na}-\mathrm{HCO}_{3}-$ $\mathrm{Cl}$ and Facies $5: \mathrm{Mg}-\mathrm{Na}-\mathrm{Cl}-\mathrm{HCO}_{3}$. The spatial distribution of hydrochemical facies of groundwater (figure 5) shows that the 'mixed' water occupies an intermediate position between the 'fresh' water and 'brackish' water comprising Facies 6: $\mathrm{Na}-\mathrm{Mg}-\mathrm{Cl}$ and Facies 7: Na-Ca-Cl. Small pockets of 'brackish' water lie within the 'mixed' water zone. These observations indicate that the 'mixed' water may have formed due to mixing of 'fresh' and 'brackish' waters within the aquifer matrix and/or in the well casing (Sahu and Sikdar 2008).

The presence of high $\mathrm{Cl}$ in 'brackish' groundwater (Facies 6: $\mathrm{Na}-\mathrm{Mg}-\mathrm{Cl}$ and Facies 7: $\mathrm{Na}-$ $\mathrm{Ca}-\mathrm{Cl}$ ) perhaps signifies a residue of seawater trapped in the sediments during their deposition under marine conditions which later underwent chemical change during its period of confinement. These waters also fall in the field of salinisation in the $\mathrm{Ca}$ against $\mathrm{Cl}$ diagram (figure $8 \mathrm{~b}$ ) and indicate restricted movement of groundwater with very low flushing. The absence of $\mathrm{Na}-\mathrm{Cl}$ facies indicates that there is no zone of stagnation in the study area. Therefore, there is a continuous low flushing action by recharge which inhibits base-exchange reaction between $\mathrm{Na-ions}$ present in clay and $\mathrm{Ca}$ and $\mathrm{Mg}$-ions present in circulating groundwater. 

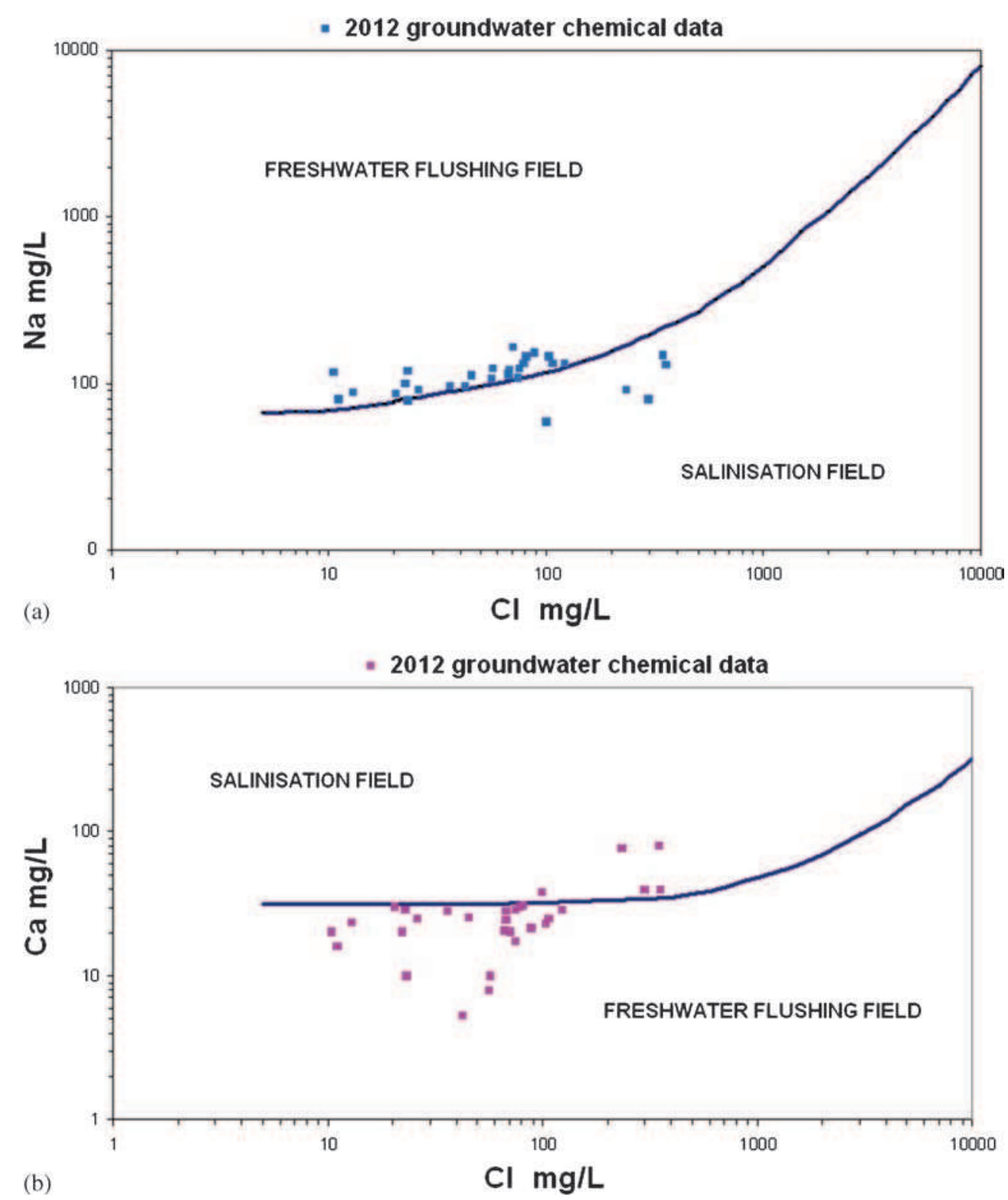

Figure 8. Plots of $\mathrm{Cl}$ against (a) Na and (b) Ca. Black lines are mixing models developed between dilute end-members and seawater (from Ravenscroft and McArthur 2004; McArthur et al. 2012a; Ravenscroft et al. 2013).

\section{Conclusion}

The topography of the study area being more or less flat results in low natural hydraulic gradients. Therefore, the groundwater hydrology of the region is particularly sensitive to pumping. Currentpumping has resulted in the formation of groundwater mounds and troughs in the area. The most prominent groundwater trough formed in the westcentral part, controls the groundwater flow of the area. Preferential groundwater flow may transport As present in the eastern part of the area to the aquifers of New Town and Kolkata. Pumping has also subjected the aquifer to fresh water flushing, enrichment of the major ions in groundwater due to weathering of rock-forming minerals, evolution of the 'mixed' water due to hydraulic mixing of 'fresh' and 'brackish' waters within the aquifer matrix and/or in-well mixing. Pumping may also likely to induce recharge from areas of known contamination suggesting deterioration of the quality of the drinking water supply in the future. Such threat in water quality is not unique but is typical of major urban centers of the world's low lying flood plains and river deltas.

This study provides new detailed information about the groundwater chemistry, factors controlling groundwater types and the geochemical evolution of groundwater in a stressed urban alluvial aquifer system in southern Bengal Basin. The study has 
also improved the understanding of a complex aquifer system in a highly exploited deltaic and floodplain area.

\section{Acknowledgements}

The first author (PS) is thankful to Department of Science and Technology (DST), Govt. of India for their financial assistance for carrying out the research work (DST Sanction No: SR/WOS-A/ES01/2010). PS also conveys thanks to Prof S A Bari, Vice Chancellor, Central University of Gujarat and Prof. M H Fulekar, Dean, School of Environment and Sustainable Development, Central University of Gujarat for providing necessary infrastructure and encouragement for the research work. The authors are also grateful to Prof Amitava Sarkar, Director, Indian Institute of Social Welfare and Business Management (IISWBM) for providing necessary infrastructure for the research work. They thank Sanghamitra Misra, Mintu Saha and Azizul Islam for assistance in the field, and Atanu Pal for chemical analysis of water samples.

\section{References}

Adar E M and Neuman S P 1988 Estimation of spatial recharge distribution using environmental isotopes and hydrochemical data, II. Application to Aravaipa Valley in southern Arizona, USA; J. Hydrol 97 279-302.

American Public Health Association (APHA) 1995 Standard Methods for the Examination of Water and Wastewater, 19th edn, American Public Health Association, American Water Works Association and Water Pollution Control Federation, Washington DC.

Azaza F H, Ketata M, Bouhlila R, Gueddari M and Riberio L et al. 2011 Hydrogeochemical characteristics and assess ment of drinking water quality in ZeussKoutine aquifer, southeastern Tunisia; Environ. Monit. Assess. $174283-298$.

Back W 1960 Origin of hydrochemical facies of groundwater in the Atlantic coastal plain; In: 22nd International Geological Congress, Copenhagen, pp. 87-95.

Ballukraya P N and Ravi R 1999 Charaterisation of groundwater in the unconfined aquifers of Chennai city, India; J. Geol. Soc. India 54 1-11.

Barnes S, Parnell J, Ruffell A H and Kalin R M et al. 2003 Groundwater circulation patterns and isotope geochemistry in the chalk of northern Ireland; Quart. J. Eng. Geol. Hydrogeol. 36(1) 59-73.

Barui N C and Chanda S 1992 Late Quaternary pollen analysis in relation to paleoecology, biostratigraphy and dating of Calcutta peat; Indian Nat. Sci. Acad. 58B(4) 191-200.

BIS (Bureau of Indian Standards) 105002003 Indian Standard drinking water specification; First Revision, pp. 1-8.

Brindha K and Elango L 2012 Impact of tanning industries on groundwater quality near a metropolitan city in India; Water Resour. Manag. 26 1747-1761.

Brindha K, Neena Vaman K V, Srinivasan K, Sathis Babu M and Elango L et al. 2014 Identification of surface watergroundwater interaction by hydrogeochemical indicators and assessing its suitability for drinking and irrigational purposes in Chennai, southern India; Appl. Water Sci. 4 159-174.

Carrilo-Rivera J J, Varsanyi I, Kovacs L O and Cardona A et al. 2007 Tracing groundwater flow systems with hydrogeochemistry in contrasting geological environments; Water Air Soil Pollut. 184 77-103.

Chakraborti D, Rahman M M, Paul K, Chowdhury U K, Sengupta M K, Lodh D, Chanda C R, Saha K C and Mukherjee S C et al. 2002 Arsenic calamity in the Indian subcontinent: What lessons have been learned? Talanta 58(1) 3-22.

Dalton M G and Upchurch S B 1978 Interpretations of hydrogeochemical facies by factor analysis; Ground Water 10 228-233.

Datta D K and Subramanian V 1997 Texture and mineralogy of sediments from the Ganges-BrahmaputraMeghna river system in the Bengal Basin, Bangladesh and their environmental implications; Environ. Geol. 30(3-4) 181-188.

Dowling C B, Poreda R J, Basu A R, Peters S L and Aggarwal P K et al. 2002 Geochemical study of arsenic release mechanisms in the Bengal Basin groundwater; Water Resourc. Res. 38(9) 12-1-12-18.

Edmunds W M and Gaye C B 1994 Estimating the spatial variability of groundwater recharge in the Sahel using chloride; J. Hydrol. 156 47-59.

EROS 2002 Shuttle Radar Topography Mission (SRTM) Elevation Data Set. National Aeronautics and Space Administration (NASA), German Aerospace Center (DLR), Italian Space Agency (ASI), the National Center for Earth Resources Observations and Science, Sioux Falls, U.S. Geological Survey.

Fendorf S, Michael H A and van Geen A et al. 2010 Spatial and temporal variations of groundwater arsenic in south and 757 southeast Asia; Science 238 1123-1127.

Ghosal U, Sikdar P K and McArthur J M et al. 2014 Palaeosol control of arsenic pollution in deltaic aquifers: The example of West Bengal, India; Groundwater, doi: 10.1111/gwat.12251.

Gibbs R J 1970 Mechanisms controlling worlds water chemistry; Science 170 1088-1090.

Hait A K, Das H K, Chakrabarty S, Ray A K and Chanda S et al. 1994a Late Quaternary Palaeontological changes in coastal Digha - a note based on floral and faunal record; Indian J. Earth Sci. 16(2) 192-198.

Hait A K, Das H K, Ghosh S, Ray A K and Chanda S et al. 1994b On the occurrence of Mangrove biota and some faunal remains from the sediments of Haldia, West Bengal in relation to its past environment; J. Palynol. 30 73-78.

Hoon Kim, Ji Hyeon, Kim R, Lee J, Jin Cheong T, Woo Yum B and Wan Chang H et al. 2004 Multivariate statistical analysis to identify the major factors governing groundwater quality in the coastal area of Kimje, South Korea; Hydrol. Process 19(6) 1261-1276.

Hoque M A, McArthur J M and Sikdar P K et al. 2012 The palaeosol model of arsenic pollution of groundwater tested along a $32 \mathrm{~km}$ traverse across West Bengal, India; Sci. Total Environ. 431 157-165.

Invernizzi A L and de Oliveira S M B 2004 Hydrochemical characterization of a watershed through factor analysis; Revista Águas Subterrâneas 18 67-77.

Kaplunovsky S A 2005 Factor analysis in environmental studies; J. Sci. Eng. B2(1-2) 54-94.

Lakshmanan E, Kannan R and Senthil Kumar M et al. 2003 Major ion chemistry and identification of hydrogeochemical processes of ground water in a part of Kancheepuram district, Tamil Nadu, India; Environ. Geosci. 10(4) 157-166. 
Lawrence F W and Upchurch S B 1982 Identification of recharge areas using geochemical factor analysis; Ground Water 20 680-687.

Lee J Y, Cheon J Y, Lee K K, Lee S Y and Lee M H et al. 2001 Statistical evaluation of geochemical parameters distribution in a ground water system contaminated with petroleum hydrocarbons; J. Environ. Quality 30 1548-1563.

Macumber P G 2003 Lenses, plumes and wedges in the Sultanate of Oman: A challenge for groundwater management; In: Water resources perspectives: Evaluation, management and policy (eds) Alsharhan A S and Wood W W, Elsevier Science, Amsterdam, The Netherlands, pp. 349-370.

McArthur J M, Banerjee D M, Hudson-Edwards K A, Mishra R, Purohit R, Ravenscroft P, Cronin A, Howarth R J, Chatterjee A, Talukder T, Lowry D and Houghton S and Chadha D et al. 2004 Natural organic matter in sedimentary basins and its relation to arsenic in anoxic groundwater: the example of West Bengal and its worldwide implications; Appl. Geochem. 19 1255-1293.

McArthur J M, Ravenscroft P, Banerjee D M, Milsom J, Hudson-Edwards K A, Sengupta S, Bristow C, Sarkar A, Tonkin S and Purohit R et al. 2008 How palaeosols influence groundwater flow and arsenic pollution: A model from the Bengal Basin and its worldwide implication; Water Resour. Res. 44 W11411, doi: 10.1029/2007WR006552.

McArthur J M, Banerjee D M, Sengupta S, Ravenscroft P, Klump S, Sarkar A, Disch B and Kipfer R et al. 2010 Migration of $\mathrm{As}$, and $3 \mathrm{H} / 3 \mathrm{He}$ ages, in groundwater from West Bengal: Implications for monitoring; Water Res. 44 4171-4185.

McArthur J M, Nath B, Banerjee D M, Purohit R and Grassineau N et al. 2011 Palaeosol control on groundwater flow and pollution distribution: The example of Arsenic; Environ. Sci. Technol. 45 1376-1383.

McArthur J M, Sikdar P K, Hoque M A and Ghosal U et al. 2012a Waste-water impacts on groundwater: $\mathrm{Cl} / \mathrm{Br}$ ratios and implications for arsenic pollution of groundwater in the Bengal Basin and Red River Basin, Vietnam; Sci. Total Environ. 437 390-402.

McArthur J M, Sikdar P K, Nath B, Grassineau N, Marshall J D and Banerjee D M et al. 2012b Sedimentological control on $\mathrm{Mn}$, and other trace elements, in groundwater of the Bengal Delta; Environ. Sci. Technol. 46 669-676.

Michael H A and Voss C I 2009a Controls on groundwater flow in the Bengal Basin of India and Bangladesh: Regional modeling analysis; Hydrogeol. J. 17(7) 15611577.

Michael H A and Voss C I 2009b Estimation of regionalscale groundwater flow properties in the Bengal Basin of India and Bangladesh; Hydrogeol. J. 17(6) 1329-1346.

Mishra P C and Patel R K 2001 Study of the pollution load in the drinking water of Rairangpur, a small tribal dominated town of north Orissa; Indian J. Environ. Ecoplan. 5(2) 293-298.

Mrklas O, Bentley L R, Lunn R D and Chu A et al. 2006 Principal component analyses of groundwater chemistry data during enhanced bioremediation; J. Water Air Soil Pollut. 169 395-411.

Mukherjee A and Fryar A E 2008 Deeper groundwater chemistry and geochemical modeling of the arsenic affected western Bengal basin, West Bengal, India; Appl. Geochem. 23 863-894.

Mukherjee A, Fryar A E and Thomas W A et al. 2009 Geologic, geomorphic and hydrologic framework and evolution of the Bengal basin, India and Bangladesh; J. Asian Earth Sci. 34 227-244.

Mukherjee A, Brömssen M V, Scanlon B R, Bhattacharya P, Fryar A E, Hasan M A, Ahmed K M, Chatterjee D,
Jacks G and Sracek O et al. 2008 Hydrogeochemical comparison and effects of overlapping redox zones on groundwater arsenic near the western (Bhagirathi sub-basin, India) and eastern (Meghna sub-basin, Bangladesh) margins of the Bengal Basin; J. Contam. Hydrol. 99(1) 31-48.

Naik S and Purohit K M 2001 Studies on water quality of river Brahmani in Sundargarh district, Orissa; Indian J. Environ. Ecoplan. 5(2) 397-402.

Ophori D U and Toth J 1989 Patterns of groundwater chemistry, Ross Creek Basin, Alberta, Canada; Groundwater 27(1) 20-26.

Osborne T H, McArthur J M, Sikdar P K and Santini J M et al. 2015 Isolation of an arsenate-respiring bacterium from a redox front in an arsenic-polluted aquifer in West Bengal, Bengal Basin; Environ. Sci. Technol. 49 41934199.

Pazand K 2013 Geochemical and hydrogeochemical evolution of groundwater in Ferdows area, northeast of Iran; Environ. Earth Sci., doi: 10.1007/s12665-013-2470-4.

Piper A M 1944 A graphic procedure in the geochemical interpretation of water analysis; Am. Geophys. Union Trans. 25 914-923.

Rajmohan N and Elango L 2006 Hydrogeochemistry and its relation to groundwater level fluctuation in the Palar and Cheyyar river basins, southern India; Hydrol. Process 20 2415-2427.

Rao Lingeswara S V 2001 Principal component of groundwater quality in Venkatagiri Taluq, Nellore district, A.P., India; Hydrol. J. 24(3) 49-54.

Ravenscroft P and McArthur J M 2004 Mechanism of regional pollution of groundwater by boron: The examples of Bangladesh and Michigan, USA; Appl. Geochem. $191413-1430$.

Ravenscroft P, McArthur J M and Hoque M A et al. 2013 Stable groundwater quality in deep aquifers of southern Bangladesh: The case against sustainable abstraction; Sci. Total Environ. 454-455 627-638.

Saha D, Dhar Y R and Sikdar P K et al. 2008 Geochemical evolution of groundwater in the Pleistocene aquifers of south Ganga Plain, Bihar; J. Geol. Soc. India 71 473482.

Sahu P 2006 Hydrogeology of the Quaternary aquifer in and around East Calcutta Wetlands, West Bengal, India; Asian Studies XXIV(1 \& 2) 72-87.

Sahu P, Michael H A, Voss C I and Sikdar P et al. 2013 Impacts on groundwater recharge areas of megacity pumping: Analysis of potential contamination of Kolkata, India, water supply; Hydrol. Sci. J. 58(6) 1340-1360.

Sahu P and Sikdar P K 2009a Assessment of aquifer vulnerability to groundwater pollution by multi-criteria analysis in and around East Calcutta Wetlands, West Bengal, India; Asian J. Water, Environ. Pollut. 6(2) 31-42.

Sahu P and Sikdar P K 2009b Understanding landuse/ landcover change in and around a freshwater peri-urban wetland ecosystem using remote sensing and geographical information system; Survey 49(1\&2) 113-126.

Sahu P and Sikdar P K 2008 Hydrochemical framework of the aquifer in and around East Calcutta Wetlands, West Bengal, India; Environ. Geol. 55(4) 823-835.

Sahu P and Sikdar P K 2011 Groundwater potential zoning of a peri-urban wetland of south Bengal Basin, India; Environ. Monit. Assess. 174 119-134.

Sánchez-Martos F, Jiménez-Espinosa R and Pulido-Bosch A et al. 2001 Mapping groundwater quality variables using PCA and geostatistics: A case study of BajoAndarax, southeastern Spain; Hydrol. Sci. J. 46(2) 227-242.

Sen P K and Banerjee M 1990 Palynoplankton stratigraphy and environmental changes during Holocene in 
Bengal basin, India; Record Palaeobotany and Palynology 62 25-35.

Sharif M U, Davis R K, Steele K F, Kim B, Kresse T M and Fazio J A et al. 2008 Inverse geochemical modeling of groundwater evolution with emphasis on arsenic in the Mississippi River valley alluvial aquifer, Arkansas, USA; J. Hydrol. 350 41-55.

Sikdar P K 2000 Geology of the Quaternary aquifers of the twin city of Calcutta-Howrah; J. Geol. Soc. India 56(8) 169-186.

Sikdar P K and Chakraborty S 2008 Genesis of arsenic in groundwater of north Bengal Plain using PCA: A case study of English Bazar Block, Malda District, West Bengal, India; Hydrol. Process. 22 1796-1809.

Sikdar P K and Sahu P 2009 Understanding wetland subsurface hydrology using geologic and isotopic signatures; Hydrol. Earth Syst. Sci. 13 1313-1323.

Sikdar P K, Sarkar S S and Dasgupta S et al. 1993 Compositional structure of groundwater in and around Gangajalhati, Bankura district, West Bengal; Indian J. Earth Sci. 201 17-27.

Sikdar P K, Sarkar S S, Palchoudhury S et al. 2001 Geochemical evolution of groundwater in the Quaternary Aquifers of Calcutta and Howrah, India; J. Asian Earth Sci. 19 579-594.

Sikdar P K and Banerjee S 2003 Genesis of arsenic in groundwater of Ganga delta - an anthropogenic model; J. Human Settlements, April 2003, 10-24.
Sikdar P K, Sahu P, Sinha Ray S P, Sarkar A and Chakraborty S et al. 2013 Migration of arsenic in multiaquifer system of Bengal Basin: Analysis via numerical modeling; Environ. Earth Sci. 70(4) 1863-1879.

Singh D F 1992 Studies on the water quality index of some major rivers of Pune, Maharashtra; Proc. Acad. Environ. Biology 1(1) 61-66.

Subba Rao N 1997 Studies on water quality index in hard rock terrain of Guntur district, Andhra Pradesh, India; National Seminar on Hydrology of Precambrian Terrains and hard rock areas, pp. 129-134.

Tiwari T N and Mishra M A 1985 A preliminary assignment of water quality index of major Indian rivers; Indian $J$. Environ. Process. 5 276-279.

Umitsu M 1987 Late Quaternary sedimentary environment and landform evolution in the Bengal lowland; Geogr. Rev. Japan 60 164-178.

Umitsu M 1993 Late Quaternary sedimentary environments and landforms in the Ganges Delta; Sedim. Geol. 83 $177-186$.

Usnoff E J and Guzman A 1989 Multivariate analysis in hydrochemistry: An example of the use of factor and correspondence Analysis; Groundwater 27(1) 7-34.

Weyhenmeyer C, Burns S J, Waber H N, Macumber P G and Matter A et al. 2002 Isotope study of moisture sources, recharge area, and groundwater flow paths within the eastern Batinah coastal plain, Sultanate of Oman; Water Resour. Res. 38(10) 2-1-2-22. 